\title{
Noise at the Neonatal Intensive Care Unit and inside the incubator
}

\author{
Eliana Moreira Pinheiro ${ }^{1}$ \\ Ruth Guinsburg ${ }^{2}$ \\ Marco Antonio de Araujo Nabuco ${ }^{3}$ \\ Tereza Yoshiko Kakehashi ${ }^{1}$
}

The goal was to identify sound pressure level (SPL) at the neonatal intensive care unit (NICU) and inside the incubator of a teaching hospital of a public university from São Paulo - SP, Brazil. SPL inside the NICU and the incubator were measured using four dosimeters in January/2010. SPL at the NICU varied from 52.6 dBA to $80.4 \mathrm{dBA}$ and inside the incubator, from $45.4 \mathrm{dBA}$ to $79.1 \mathrm{dBA}$. SPL both at the NICU and inside the incubator are above the recommended values, but levels were higher at the NICU than inside the incubator. Although there are some specific factors related to SPL inside the incubator, the NICU and incubator acoustic features present a system: an increase/decrease in SPL at the NICU usually tends to increase/decrease SPL inside the incubator. The study points to the need for simultaneous monitoring of SPL at the NICU and inside the incubator.

Descriptors: Noise; Intensive Care, Neonatal; Neonatal Nursing; Humanization of Assistance; Infant, Newborn.

\footnotetext{
${ }^{1}$ RN, Ph.D. in Nursing, Escola Paulista de Enfermagem, Universidade Federal de São Paulo, SP, Brazil. E-mail: Eliana elianapinheiro@hotmail.com, Tereza - terezayk@ig.com.br.

${ }^{2}$ Physician, Ph.D. in Pediatrics, Departamento de Pediatria, Universidade Federal de São Paulo, SP, Brazil. E-mail: ruthgbr@netpoint.com.br.

${ }^{3}$ Electrical Engineer, Ph.D. in Mechanical Engineering, Instituto Nacional de Metrologia, Normalização e Qualidade Industrial, Rio de Janeiro, RJ, Brazil. E-mail: nabuco@inmetro.br.
}

Corresponding Author:

Tereza Yoshiko Kakehashi

Rua Napoleão de Barros, 754

Vila Clementino

CEP: 04024-002, São Paulo, SP, Brasil

E-mail: terezayk@ig.com.br 


\section{Ruído na Unidade de Terapia Intensiva Neonatal e no interior da incubadora}

Este trabalho teve por objetivo identificar o nível de pressão sonora (NPS) da Unidade de Terapia Intensiva Neonatal (UTIN) e do interior da incubadora de um hospital escola de uma universidade pública de São Paulo, SP, Brasil. Como método para essa identificação, tanto do NPS da UTIN como do NPS da incubadora, foram utilizados quatro dosímetros, em janeiro de 2010. Os resultados obtidos apontam que o NPS da UTIN variou entre $52,6 \mathrm{dBA}$ e 80,4 dBA, e que o NPS do interior da incubadora foi de 45,4dBA a 79,1dBA. Evidenciou-se que tanto o NPS da UTIN como o do interior da incubadora estão acima dos recomendados, sendo mais altos na UTIN do que na incubadora. Embora haja alguns fatores específicos relacionados ao NPS no interior da incubadora, perfis acústicos da UTIN e da incubadora são como sistema: elevação/redução do NPS da UTIN, geralmente, tende a elevar/reduzir o NPS no interior da incubadora. Portanto, pode-se concluir que o presente estudo aponta para a importância do monitoramento simultâneo dos NPS da UTIN e do interior da incubadora.

Descritores: Ruído; Terapia Intensiva Neonatal; Enfermagem Neonatal; Humanização da Assistência; Recém-Nascido.

\section{Ruido en la Unidad de Terapia Intensiva Neonatal y en el interior de la incubadora}

Se tuvo por objetivo identificar el nivel de presión sonora (NPS) de la Unidad de Terapia Intensiva Neonatal (UTIN) y del interior de la incubadora de un hospital escuela de una universidad pública de Sao Paulo-SP, Brasil. EI NPS de la UTIN y de la incubadora fueron obtenidos por cuatro dosímetros en enero de 2010. EI NPS de la UTIN varió entre 52,6 dBA y 80,4 dBA y el del interior de la incubadora fue de $45,4 \mathrm{dBA}$ a $79,1 \mathrm{dBA}$. Tanto el NPS de la UTIN como el del interior de la incubadora son mayores que lo que recomendado, siendo más altos en la UTIN que en la incubadora. A pesar de que existen algunos factores específicos relacionados al NPS en el interior de la incubadora, los perfiles acústicos de la UTIN y de la incubadora son como un sistema, es decir: la elevación/reducción del NPS de la UTIN generalmente tiende a elevar/reducir el NPS en el interior de la incubadora. Se concluye que muy importante la monitorización simultánea del NPS de la UTIN y del interior de la incubadora.

Descriptores: Ruido; Cuidado Intensivo Neonatal; Enfermería Neonatal; Humanización de la Atención.

\section{Introduction}

Initial studies on the importance of noise in the NICU environment data back to the 1970's, but became more intense as from the 1990's, as its immediate effects on neonates' clinical condition and developmental consequences were verified, as well as on team wellbeing, affecting professional performance(1). Recent studies focus on sound pressure level (SPL) monitoring at the Neonatal Intensive Care Unit (NICU) or inside the incubator, performed from the perspective of developmental and individualized care for premature newborns hospitalized at neonatal units.

The developmental care focus was introduced in the 1980's, as a strategy to change NICU environmental conditions with a view to neonatal wellbeing and safety by reducing noise levels and lighting intensity, minimal handling, provision of longer rest periods, among others $^{(2)}$. 
Noise control can represents a difficult task for nurses, as NICU noise mostly derives from care activities and professional conduct ${ }^{(3-4)}$.

Incubators, on the other hand, which M. Tarnier idealized in 1889, were introduced for the first time in neonatal care history at the Maternité de Paris in 1881. They constituted one of the most important advances in care delivery to premature newborns(5). Inside the incubator, filtered air is provided with a view to protection against infections, controlled temperature and moisture for adjustment to physiological needs. For a long time, incubators were considered the ideal micro-environment for neonates. Recent studies, however, mention incubator stay as one of the factors for the development of deafness in newborns(6) or which enhance the adverse effects of other necessary treatment measures. Incubators partially serve as barriers against the penetration of environmental sound, but the sound their own functioning and care delivery produce reverberation against the hard wall of the dome, amplifying the noise that reaches the neonate ${ }^{(7)}$.

Transforming the high-complexity NICU, which is generally threatening for parents and hostile for neonates and professional in an environment of care and welcoming, is related with humanization of care ${ }^{(8)}$, which can be understood as a process that considers the singularity of human beings, permitting the expression of their subjectivity. It presupposes the good use of equipment, procedures and knowledge associated with an effective process of communication, listening and dialogue, enhancing affection ${ }^{(9)}$. Thus, if one of nursing's care foci is the environment, a safe workspace can be created for the performance of health team activities.

The researchers depart from the premise that a relation exists between SPL inside the incubator and SPL in the NICU environment. Thus, knowing these two environments' acoustic profile at the same time permits the development of more specific measures for environmental noise management. This study can contribute for professionals to incorporate environmental health as an essential component of safe care delivery to newborns and can also enhance occupational health for NICU work. This study aims to identify SPLs at the NICU and inside the incubator at a teaching hospital affiliated with a public university in São Paulo, SP, Brazil.

\section{Methods}

This quantitative and descriptive study was accomplished at an NICU room and inside the incubators of a teaching hospital in São Paulo-SP, Brazil, between January $24^{\text {th }}$ and $30^{\text {th }} 2010$.

The capacity of this room is 4 beds, measuring approximately $23.80 \mathrm{~m}^{2}, 3.40 \mathrm{~m}$ high, vinyl floor covering, brick walls, concrete roof and glass windows with screens that are permanently open, exposing the environment to street noise. The room is located next to the nursing station, with the phone, controlled drug inventories and staff performing some tasks. Next to the nursing station is the corridor, on which health professionals, students and teachers circulate and remain during clinical discussions and the execution of medical prescriptions. No air-conditioning is available in the environment. All incubators used at the neonatal unit were manufactured by FANEM $^{\circledR}$, model C186T S.

Four dosimeters were used simultaneously for data collection, three of which served to register SPL at the NICU and one inside the incubator. The three dosimeters were hung at the center of three room quadrants, at different heights: $1.65 \mathrm{~m} ; 1.70 \mathrm{~m}$ and $1.90 \mathrm{~m}$, at a distance of at least $1 \mathrm{~m}$ from the walls, floor and roof, in line with Brazilian recommendations ${ }^{(10)}$. The researchers chose to place them at different heights so that the three microphones would not be located in parallel with any room surface, so as to reduce the possibility of reducing the influence of stationary sound waves in the environment.

To register the SPL inside the incubator, the dosimeter microphone was placed at approximately 20 $\mathrm{cm}$ from the baby's ear(11). The brand of all dosimeters used to collect the data was Quest 400.

Initially, to decide in what incubator to measure the SPL, the researchers identified the infant with the highest Score for Neonatal Acute Physiology Version II (SNAPII) among the neonates at the unit. This criterion was adopted because this score assesses the risk of neonatal mortality(12). During this period, the dosimeter was transferred to another incubator twice, as a result of the need for the newborn to leave the NICU.

The four dosimeters, which can register SPL every minute, were configured as follows: fast response time (fast), measuring the sound pressure level in decibel $(d B)$ and weighted in frequency $A d B(A)^{(13)}$. Scale $A$ $(d B A)$ is the filtering method that mimics the receptive characteristics of the human ear. It is indicated to apprehend continuous noise of equivalent sound pressure level $(\text { Leq })^{(14)}$. All devices were programmed to operate at SPL intervals between 40 and $140 \mathrm{~dB}(\mathrm{~A})$. Thus, the duration of each measured noise level was exactly registered and stored, resulting in a set of data in the form of Leq, $\mathrm{Leq}_{\max } \mathrm{Leq}_{\min }$ for statistical treatment 
and analysis. The Leq is the integrated mean sound level during a certain time period. This measure is important because it is known that not only high noise levels, but also their duration provoke human hearing lesions.

Every day, batteries were changed, Leq was registered and the four dosimeters were calibrated with a QC10 calibrator at the end of each shift. Leq records were obtained when turning off the dosimeters at the end of the shift and turning them on again at the start of the next shift, on all weekdays.

The possibility of changes in the NICU professionals' conduct was considered due to the presence of the researchers and devices. Therefore, the team was desensitized for one week. During that period, the dosimeter microphone was placed inside the incubator and the three dosimeters were hung from the roof. Battery change, Leq recording and recalibration were simulated at the end of each shift.

The data collection strategy previewed that the four devices would remain connected simultaneously at the NICU and inside the incubator 24 hours per day, totaling 168 hours for each environment during one week. Six hours of records were lost at the NICU due to a technical measurement problem with one of the dosimeters. Besides, before proceeding with data analysis, 30 minutes of records were discarded at the start and end of each shift, considering the possibility that noise would be provoked while handling the devices due to calibration and reinstallation, influencing Leq for the period. This operation, sequentially performed in each dosimeter, took an average 30 minutes. Thus, 16 hours and 30 minutes of records were discarded. Hence, the sample comprised 151 hours and 30 minutes of SPL records at the NICU and inside the incubator.

The SPL records the dosimeter inside the incubator and the three devices installed at the NICU were transferred to QuestSuite for Excel software, which permitted data treatment. For data analysis, continuous and equivalent (Leq) SPLs were considered, as well as the maxima $\left(\operatorname{Leq}_{\max }\right)$ and minima $\left(\mathrm{Leq}_{\min }\right)$ of the data all dosimeters registered during the collection period. The spatial average of the Leq levels the three NICU dosimeters obtained was calculated to realistically capture the environmental noise people of different heights experience who move around the room to perform their activities. The standard deviations on different weekdays and shifts were also calculated.

Before the start of data collection, approval was obtained from the Institutional Review Board at Universidade Federal de São Paulo, as well as authorization from hospital management (process No: 0391/07).

\section{Results}

The results reveal that SPLs at the NICU and inside the incubator exceed regulatory entities' recommendations.

The Brazilian Association of Technical Standards (ABNT) recommends levels between 35 and $45 \mathrm{dBA}$ for hospital environments(10); the American Academy of Pediatrics (AAP) ${ }^{(15)}$ and the Committee to Establish Recommended Standards for Newborn ICU Design ${ }^{(16)}$ recommend avoiding SPL above $45 \mathrm{dBAe}$ and, similarly, the World Health Organization proposes $45 \mathrm{dBA}^{(17)}$.

As for SPL inside the incubator, the ABNT establishes $\mathrm{L}_{\text {eq }}$ levels below $60.0 \mathrm{dBA}^{(18)}$ and the AAP below $58.0 \mathrm{dBA}$, as the maximum level permitted ${ }^{(15)}$.

SPL measurement results at the NICU indicate that the highest mean $\mathrm{L}_{\text {eq }}$ was $80.4 \mathrm{dBA}$ on Saturday afternoon. On the other hand, the lowest mean $L_{e q}$ was $52.6 \mathrm{dBA}$, measured during the Monday night shift (Figure 1). In that environment, $\mathrm{L}_{\mathrm{eq}}$ during the week under analysis was $27.8 \mathrm{dBA}$.

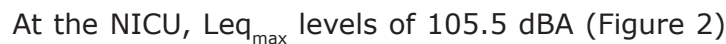
were measured during the Saturday afternoon shift, and Leq $_{\text {min }}$ levels of 47.7dBA on Monday night (Figure 3).

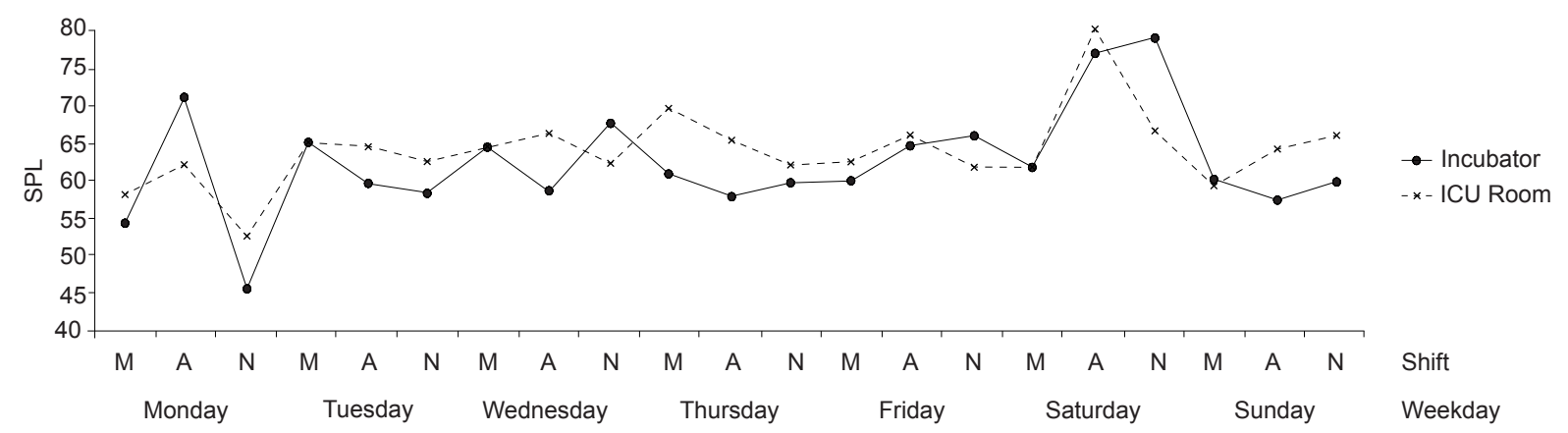

Figure 1 - Mean Leq (dBA) at the NICU and inside the incubator, per shift and weekday. São Paulo, SP, Brazil, 2010 


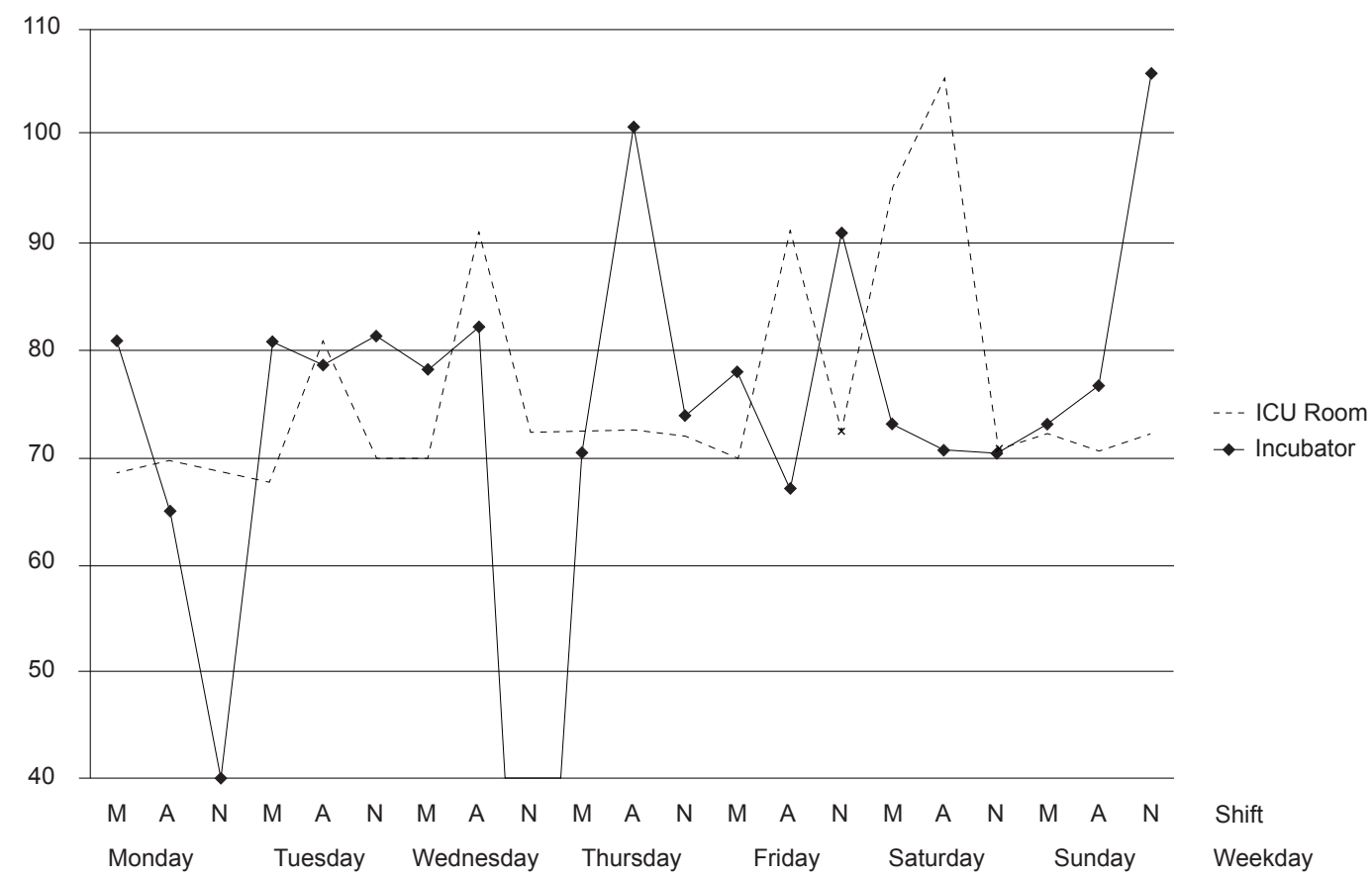

Figure 2 - Leq $_{\max }(\mathrm{dBA})$ levels at the NICU and inside the incubator per shift and weekday. São Paulo- SP, Brazil, 2010

Inside the incubators, the highest Leq $_{\text {mean }}$ recorded was 79.1dBA during the Saturday night shift, while the lowest was $45.4 \mathrm{dBA}$ on Monday night (Figure 1). The range of $\mathrm{Leq}_{\text {mean }}$ was $33.7 \mathrm{dBA}$. The highest $\mathrm{Leq}_{\max }$ registered was 106.0 dBA (Figure 2) during the Sunday night shift and the lowest $L_{\text {min }}$ was $48.0 \mathrm{dBA}$ on Saturday night (Figure 3).

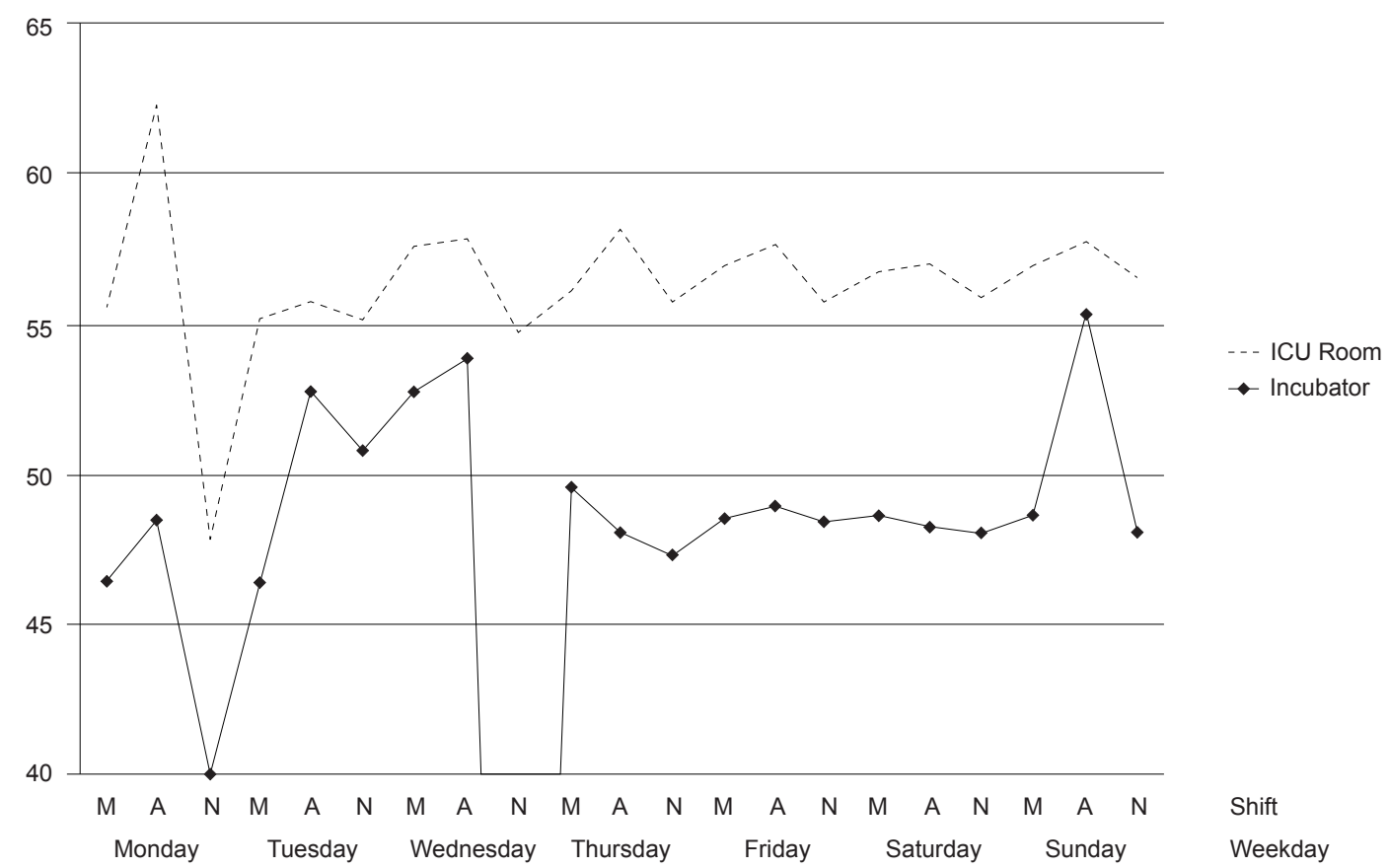

Figure $3-$ Leq $_{\min }(\mathrm{dBA})$ at the NICU and inside the incubator per shift and weekday. São Paulo, SP, Brazil, 2010 


\section{Discussion}

Noise is considered one important stress factor for neonates and NICU professionals. In this research, it was verified that both environments are considerably noisy. When assessing the acoustic environment, it should be taken into account that the NICU and the incubator work as a system. A study demonstrated that, in general, SPLs inside the incubator are higher than at the NICU(19). Environmental sound at the NICU partially cross the acrylic wall of the incubator dome which, in turn, produces its own sound, resulting from engine functioning, care activities and the infant's own manifestations(20-21). As the environment is closed, these sounds reverberate against the hard dome wall, amplifying the noise that reaches the neonate ${ }^{(7)}$. A study accomplished in São Paulo found higher SPL inside incubators with a closed than with an open porthole(21). The infant's behavioral status is one of the important determinants of SPL inside the incubator. It was found that a newborn's agitation can raise the SPL by up to $20 \mathrm{dBA}^{(22)}$. Another variable related to SPL rise inside the incubator is the baby's weight. Considering both environmental factors and factors inside the incubator, an inverse relation is observed between the infant's weight and SPL inside the incubator. Thus, the lower the infant's weight, the higher the SPL. The possible understanding of this phenomenon is related to the related surfaces' reverberation and absorption of sounds. Very low birth weight newborn's small body surface and the smaller diaper size absorb less noise, enhancing reverberation and increasing SPL inside the incubator ${ }^{(20)}$. In this study, the infants attended in incubators where SPLs were verified were classified as extremely low birth weight premature infants. Thus, they were submitted to frequent invasive interventions, consequently increasing painful experiences and psychomotor agitation. These factors may have contributed to SPL increases inside the incubator. With a view to reducing noise inside the incubators, minimizing reverberation, one study assessed the effect of a foam panel placed inside the incubator and observed a decrease in background noise from $47 \mathrm{dBA}$ to $43 \mathrm{dBA}$ and in infant crying from $79 \mathrm{dBA}$ to $69 \mathrm{dBA}$. Likewise, significant reductions were observed in noise other sources provoked, such as monitor alarms, equipment engines and porthole closing(23). The importance of these results is highlighted as, on the logarithmic noise measurement scale in decibels, a 3 $\mathrm{dB}$ rise/drop means an SPL increase/decrease by about $50 \%{ }^{(19)}$.
As opposed to what this study described above, SPL at the NICU was higher than inside the incubator most of the time. This result is in line with research data that compared the SPLs infants are exposed to inside incubators and heated cribs and found higher levels in heated cribs, between 62 and $70 \mathrm{dBA}$, than in incubators, with SPL ranging between 60 and $67 \mathrm{dBA}^{(24)}$. This result is partially accredited to the incubator selection criterion: the researchers always chose those incubators with clinically more critical infants as assessed by SNAP II, thus, with minimal handling indications. At the same time, the newest and best life support equipment and incubators available at the unit were always destined at these infants. This fact supposedly contributed to reduce SPL inside the incubators that were analyzed, as verified in the study that found a decrease in up to $4 \mathrm{dBA}$ between SPLs in the newest and older incubators ${ }^{(22)}$. In addition, as this is a teaching hospital, a large number of professionals and students are always circulating at this unit. Hence, clinical discussions are more frequent and, despite efforts made to hold these sessions on the corridor, unavoidably, situations arise in which various discussions groups are happening at the same time, some of which find no space at the unit, except at the room where the infant is in. As the noise voices and device alarms provoke influences the environment more than the incubator ${ }^{(21)}$ and as the centers of the two quadrants in which the dosimeters were installed were located above the circulation space, where professionals join for discussions if necessary, the researchers suppose that the SPL they captured influenced environmental noise more than noise inside the incubator.

One aspect that should always be reminded in noise management during neonatal care is that, at the NICU, infants are exposed to impact noise, which provoke disorganization of their physiological condition, as well as continuous noises that do not permit their recovery. Specialists consider the phenomenon of habituation in neonates, defined as the ability to decrease behavioral responses to repetitive stimuli, permitting lower energy spending or greater ability to continue sleeping. When environmental stimuli are very strong and continuous though, habituation is compromised and the infant reacts to these stimuli until (s)he gets exhausted(25).

At the NICU under analysis, one of the crucial aspects to reduce SPL refers to the adequacy of architectonic and material conditions. At this unit, some factors exist that do not enhance the maintenance of comfortable acoustic levels, such as: the nursing station and the place where health professionals perform prescriptions 
and evolutions are located on the corridor, directly communicating with the room whose door is kept open most of the time. There is no room external to the NICU designated for reception either. Thus, the bell noise can be heard inside the sector. The ringing of the telephone placed on the corridor desk enhances noise inside the unit even more. The hospital is located in an area with intense traffic and, as there is no air-conditioning at the NICU, the windows are often kept open, enhancing the influence of external noise.

Handling the equipment adequately and reducing its usage time can also represent important noise reduction strategies ${ }^{(26)}$. A study accomplished in 2006 found that SPLs decreased by up to $4 \mathrm{dBA}$ in new incubators when compared to others used for 6 to 9 years $^{(21)}$. In this study, the incubators' mean usage time is 15 years. This situation does not differ from the reality at most Brazilian health institutions, in which high-tech equipment is intensively used, without the possibility of preventive maintenance programs.

\section{Conclusions}

As SPLs both at the NICU and inside the incubator exceed regulatory entities' recommendations, institutions and professionals need to develop efforts to bring down this noise level, as research different authors have accomplished in different circumstances has sufficiently documented the harmful effects.

Noise management at NICU and inside incubators involves architectural, material and human resource factors. Implementing changes that cover all of these aspects simultaneously go beyond many institutions' possibilities. The ripple effect of noise should be reminded though: when interacting, different stimuli can enhance the SPL, that is, the higher equipment noise, the higher professionals raise their voice and the longer they take to respond to alarms. Hence, when thinking in the opposite sense, it can be expected that, the more silent the NICU, the more sensitive professionals will become to infants' crying and agitation and the more readily they will answer the alarms. Therefore, it is concluded that each unit should start its reduction program based on what its reality permits, and will probably achieve positive repercussions in terms of other aspects.

\section{References}

1. Philbin MK, Lickliter R, Graven SN. Sensory experience and the developing organism: a history of ideas and view to the future. J Perinatol. 2000;20:s2-s5.
2. Symington A, Pinelli JM. Distilling evidence on developmental care: a systematic review. Adv Neonat Care. 2002;2(4):198-222.

3. Scochi CGS, Riul MJS, Garcia CFD, Barradas LS, Pileggi SO. Cuidado individualizado ao pequeno prematuro: o ambiente sensorial em unidade de terapia intensiva neonatal. Acta Paul Enferm. 2001;14(1):9-16.

4. Philbin MK, Robertson A, Hall III JW. Recommended permissible noise criteria for occupied, newly constructed or renovated hospital nurseries. Adv Neonat Care. 2008;8(5):11-5.

5. Auvard PVA. De la couveuse pour enfants. Arch Tocol Maladies Femmes Enfants Nouveau-nés. [periódico na Internet].1883. [acesso 24 jul 2010]; 14:577-609. Disponível em: http://www.neonatology.org/classics/ auvard/auvard.html

6. American Academy of Pediatrics. Joint Committee on Infant Hearing. Year 2007 Position Statement: principles and guidelines for early hearing detection and intervention programs. Pediatrics. 2007;120;898-921.

7. Philbin MK. Planning the acoustic environment of a neonatal intensive care unit. Clin Perinatol. 2004;31:331-52.

8. Kakehashi TY, Pinheiro EM, Pizzarro G, Guilherme A. Nível de Ruído em Unidade de Terapia Intensiva Neonatal. Acta Paul Enferm. 2007;20(4):404-9.

9. Silva LJ, Silva LR, Christoffel MM. Tecnologia e humanização na unidade de terapia intensiva neonatal. Rev Esc Enferm USP. 2009;43(3):684-9.

10. Associação Brasileira de Normas Técnicas (ABNT). NBR 10152: Níveis de ruídos para conforto acústico. Rio de Janeiro: Associação Brasileira de Normas Técnicas; 2000.

11. Azevedo MF, Vieira RM, Vilanova LCP. Desenvolvimento auditivo de crianças normais e de alto risco. Plexus: São Paulo; 2001.

12. Silveira RC, Schlabendorff M, Procianoy RS. Valor preditivo dos escores de SNAP e SNAP- PE na mortalidade neonatal. J Pediatr. 2001;77:455-60.

13. Robertson A, Kohn J, Vos P, Cooperpeel C. Establishing a noise measurement protocol for neonatal intensive care units. J Perinatol. 1998 March-Apr;18(2):126-30.

14. Pereira RP, Toledo RN, Amaral JLG do, Guilherme A. Qualificação e quantificação da exposição sonora ambiental em uma unidade de terapia intensiva geral. Rev Bras Otorrinolaringol. 2003;69(6):766-71.

15. American Academy of Pediatrics. Committee on environmental health. Noise: a hazard for the fetus and newborn. Pediatrics. 1997 Oc;100(4):724-7. 
16. Committee to Establish Recommended Standards for Newborn Icu Design. Recommended standards for newborn ICU design: report of the seventh consensus conference on newborn ICU design. Clearwater Beach, Florida: Feb 2007 [acesso 30 maio 2011]. Disponível em: http://www.nd.edu/ nicudes/stan\%2023.html.

17. World Health Organization (WHO). Guidelines values. London; 1999. [acesso 2 nov 2004]. Disponível em: http://www. who.int/docstore/peh/noise/Commnoise4. htm

18. Associação Brasileira de Normas Técnicas - ABNT. NBR IEC 60601-2-19: equipamento eletromédico parte 2: prescrições particulares para segurança de incubadoras de recém-nascido (RN). Rio de Janeiro: ABNT; 1997.

19. Ellander G, Hellström G. Reduction of noise levels in intensivecare unitsforinfants: evaluation ofanintervention program. Heart \& Lung. 1995;24(5):376-9.

20. Johnson NA. Neonatal response to control of noise inside the incubator. Pediatr Nurs. 2001;27(6):600-5.

21. Lichtig I, Maki K. Estudo de níveis de ruídos ambientais e de ruídos gerados em incubadoras em uma unidade de terapia intensiva neonatal. Pediatria. 1992;14(1):30-4.

22. Byers JF, Waugh WR, Lowman LB. Sound level exposure of high-risk infant in different environmental conditions. Neonat Network. 2006; 25(1):25-32.

23. Altancu E, Akman I, Kulekci S, Akdas F, Bilgen $H$, Ozek E. Noise level in neonatal intensive care unit and use of sound absorbing panel in the isolette. Int J Ped Otol. 2009 Jul;73(7):951-3.

24. Jockheer P, Robert M, Abury J-C, De Brouwer C. Le bruit en néonatolgie, impact du personnel hospitalaier. Presse Med. 2004;33:1421-4.

25. Philbin MK, Klaas P. The full-term and premature newborn: hearing and behavioral responses to sound in full-termnewborns. J Perinatol. 2000;20:s67-s75.

26. Rodarte MDO, Scochi CGS, Leite AM, Fujinaga CI, Zamberlan NE, Castral TC. O ruído gerado durante a manipulação das incubadoras: implicações para o cuidado de enfermagem. Rev. Latino-Am. Enfermagem. 2005;13(1):79-85. 